\title{
Influence of landscape structure on the abundance of Desmodus rotundus (Geoffroy 1810) in northeastern Yucatan, Mexico
}

\section{Influencia de la estructura del paisaje en la abundancia de Desmodus rotundus (Geoffroy 1810) en el noreste de Yucatán, México}

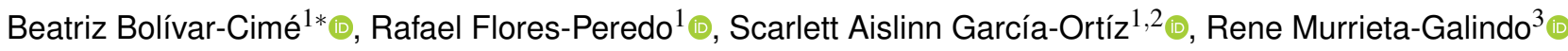 \\ Javier Laborde ${ }^{4}$ (D) \\ ${ }^{1}$ Instituto de Investigaciones Forestales, Universidad Veracruzana, Parque Ecológico "El Haya", Col. Benito Juárez, CP. 91070, Xalapa, \\ Veracruz, México. \\ ${ }^{2}$ Centro de Investigaciones Tropicales, Universidad Veracruzana, José María Morelos 44, Col. Centro, CP. 91000, Xalapa, Veracruz, \\ México. \\ ${ }^{3}$ El Colegio de Veracruz, Desarrollo Regional Sustentable, Carrillo Puerto No. 26, Col. Centro, CP. 91000, Xalapa, Veracruz, México. \\ ${ }^{4}$ Red de Ecología Funcional, Instituto de Ecología A.C., Carretera antigua a Coatepec No. 351, El Haya, CP. 91070, Xalapa, Veracruz, \\ México. \\ *Corresponding author: bolivar_cime@yahoo.com
}

Scientific article received: August 21, 2018 accepted: January 28, 2019

\begin{abstract}
Although the transformation of landscapes by human activity can negatively affect the populations of several bat species, other species may benefit from these transformations. One of such species is the vampire bat, Desmodus rotundus, which can often be found in landscapes dominated by livestock activities. Furthermore, there are certain structural landscape characteristics that could be positively influencing the abundance of the vampire bat. To assess this possibility, eight sampling sites in northeastern Yucatan, Mexico were monitored from June 2010 to February 2012. Four sites were located in forest fragments amongst a highly fragmented landscape dominated by pastures dedicated to livestock activities, and four sites were located within continuous tropical semi-deciduous forest with almost no fragmentation. Forest fragmentation was characterized around the sampling sites within a $2.5 \mathrm{~km}$ radius using SPOT images from 2010, and five landscape variables were calculated using FRAGSTATS. The results showed that landscape heterogeneity and an agricultural aggregation index both had a significant effect on the abundance of the vampire bat. Our results showed that $D$. rotundus abundance in northeastern Yucatan, Mexico was favored by extensive pastures as well as by landscape characteristics associated with intense forest fragmentation. However, the presence of some remnants of forest cover probably enhance the movements and persistence of this species. To reduce the negative impact of the vampire bat presence in these areas dedicated to livestock ranching activities, effective preventive vaccination campaigns could be an important strategy.
\end{abstract}

Key words: Landscape heterogeneity, livestock, vampire bat, vegetation corridor.

RESUMEN. Aunque la transformación del paisaje por actividades humanas ha afectado negativamente las poblaciones de varias especies de murciélagos, existen otras que se han beneficiado por esta transformación. Una de ellas es el murciélago vampiro, Desmodus rotundus, que puede ser frecuentemente registrado en paisajes dominados por actividades ganaderas. Además, existen ciertas características en la estructura del paisaje que podrían influenciar positivamente la abundancia del murciélago vampiro. Para evaluar esto, se monitorearon ocho sitios en el noreste de Yucatán, México, de junio de 2010 a febrero de 2012. Cuatro sitios fueron localizados en fragmentos de selva inmersos en un paisaje dominado por pastizales dedicados a la ganadería y con una alta intensidad de fragmentación; otros cuatro sitios se ubicaron en una zona con una cobertura de selva subcaducifolia más continua y una baja intensidad de fragmentación. Se analizó la fragmentación alrededor de los sitios de estudio, en un radio de $2.5 \mathrm{~km}$, utilizando una imagen SPOT del 2010 y posteriormente a través del cálculo de cinco variables del paisaje empleando el programa FRAGSTATS. Se encontró que la heterogeneidad del paisaje y la agregación de las áreas agropecuarias tuvieron un efecto significativo en la abundancia del murciélago vampiro. Los 
resultados del presente trabajo indican que $D$. rotundus en el noreste de Yucatán, México, es favorecido por la presencia de grandes extensiones de pastizales ganaderos, así como un paisaje con selvas altamente fragmentadas. Para reducir el impacto negativo de la presencia del vampiro común en áreas dedicadas a la producción de ganado, la efectividad de las campañas de vacunación bovina podría ser una estrategia importante.

Palabras clave: Heterogeneidad del paisaje, ganado, murciélago vampiro, corredores de vegetación.

\section{INTRODUCTION}

Habitat fragmentation is defined as a process in which a continuous habitat has been divided into smaller habitat patches that are surrounded by one or several types of landscape matrices (Bennett and Saunders 2010), usually of anthropic origin. Globally, habitat fragmentation has been regarded as the main cause of biodiversity loss and ecosystem degradation (Wilson et al. 2016), which result from agricultural and forestry activities (García 2011). In the Mexican state of Yucatan, there have been extensive changes in land cover through deforestation, where tropical deciduous forest, tropical semi-deciduous forest and coastal dune vegetation are the most affected types of vegetation (Durán-García and García-Contreras 2010, Ramírez-Delgado et al. 2014). Only 18\% of the structurally heterogeneous and diverse native vegetation of this state remains, while $82 \%$ has been transformed by human activities, especially livestock farming (INEGI 2011). In Yucatan, this activity has considerable ecological costs and low productivity due to inappropriate soils (Andrade 2010), with the highest density of livestock concentrated in the northeastern region (Robinson et al. 2014). Therefore, the northeastern portion of Yucatan state is represented by a landscape with extensive cattle ranches and some remnants of mature and secondary forests (Durán-García and García-Contreras 2010), forming a heterogeneous vegetation mosaic with different intensities of disturbances and management.

Although drastic changes in land use may have negative impacts on the richness and abundance of most wildlife groups (Martinuzzi et al. 2015), other taxa, such as bats of the subfamilies Stenodermatinae and Desmodontinae (family Phyllostomidae), may be favored (Fenton et al. 1992, GarcíaMorales et al. 2013). One of these species is the hematophagous bat Desmodus rotundus (Geoffroy
1810), which easily adapts to human disturbances and is commonly found within fragmented landscapes dominated by different types of landscape matrices. Several authors have documented that $D$. rotundus can inhabit different types of man-made habitats, such as agroforestry plots, silvopastoral systems, pastures and secondary forests, and the species has also been found in patches of old-growth or undisturbed forests (Kalko and Handley 2001, García-Morales et al. 2013). Some studies have reported an increase in the abundance of this bat species in tropical areas of America, and it has been linked to the increase in the number of livestock herds available as its food source (Medellín et al. 2000, Mialhe 2014, Bobrowiec et al. 2015). The presence of $D$. rotundus has been constantly monitored through animal health programs because this bat species is the only known vector of bovine paralytic rabies and may cause significant economic losses (Mayen 2003). Although it is usually assumed that vampire bats provoke weight loss or reduced milk production in animals that are recurrently bitten, the evidence in favor of this hypothesis is limited (Anderson et al. 2012).

During 2012-2013, 146 cases of bovine paraIytic rabies were recorded in Mexico, where the state of Yucatan had the third highest number of cases; however, in this state no more than 37 cases were reported per year (Bárcenas-Reyes et al. 2015, SENASICA-SAGARPA 2016). In Mexico, it has been estimated that the prevention of this disease through livestock vaccination protocols generates a benefit six times greater than its cost; in contrast, the protocols aimed at controlling $D$. rotundus populations have currently resulted in excessive costs compared to their benefits (Anderson et al. 2012).

The vampire bat is one of the most common bat species in northeastern Yucatan (MacSwiney et al. 2007), which is a region characterized by the drastic transformation of land cover. In this scenario, 
the objective of the present work was to determine the effect of landscape structure variables, obtained from remote sensing analysis, on the abundance of $D$. rotundus. Because the presence of $D$. rotundus has been related with the increase of man-made pastures for cattle ranching (Mialhe 2014, Bobrowiec et al. 2015), we predicted that the abundance of this bat species might be higher in more fragmented areas, specifically those with little forest cover and more surface area occupied by pastures.

\section{MATERIALS AND METHODS}

\section{Study area}

The study was conducted in the municipalities of Buctzotz, Espita and Tunkas located in the northeastern portion of the state of Yucatán, Mexico, between $20^{\circ} 50^{\prime}-21^{\circ} 20^{\prime} \mathrm{N}$ and $87^{\circ} 50^{\prime}-89^{\circ} 00^{\prime}$ $\mathrm{W}$. The region is dominated by vegetation relicts of tropical semi-deciduous forest and man-made pastures (Flores and Espejel-Carvajal 1994). The climate is sub-humid warm with summer rains (Aw0), according to García (2004), the annual rainfall is 900$1037 \mathrm{~mm}$ and the average temperature ranges from 25.9 to $26.4{ }^{\circ} \mathrm{C}$ (Barber et al. 2001).

The study area is characterized by two contrasting types of landscape matrices. The first type is dominated by man-made pastures, where the forest cover (tropical semi-deciduous forest and its secondary vegetation) is limited to several small patches (mean area:1.4 ha, density: 37 patches/100 ha) and corridors. This pasture matrix was assessed in the municipality of Buctzotz, where more than $90 \%$ of its surface has been deforested for cattle ranching (INEGI 2011), occupying the second place at the state in number of cattle heads $(27,086)$ during 2007 (INEGI 2007). The second type of landscape matrix was dominated by tropical semi-deciduous forest and secondary forest in different stages of succession (hereafter continuous forest); this matrix also had small isolated patches (mean area: 0.9 ha, density: 4.2 patches $/ 100$ ha) dedicated to slash-and-burn agriculture. Continuous forest matrix was represented by the municipalities of Tunkas and Espita, as each retains more than $70 \%$ of their forest cover (INEGI
2011), and it is also possible to find free-ranging cattle in these municipalities. In 2007, Espita had 5,388 registered cattle heads and Tunkas had 2432 (INEGI 2007).

In this study, we selected eight sampling sites. Four sites were small forest fragments surrounded by pasture matrix (Buctzotz), and four sites were within extensive areas of continuous forest matrix (Tunkas and Espita). The minimum distance between sampling sites was $5 \mathrm{~km}$ (Figure 1). The study was conducted from June 2010 to February 2012, encompassing two rainy seasons (May-October) and two dry seasons (November-April) (Duch 1988).

\section{Landscape structure of sampling sites}

A SPOT image from 2010 with a resolution of $2.5 \mathrm{~m}$ per pixel was classified using $\mathrm{PCl}$ Geomatics ${ }^{\circledR}$ V8.2 software. The image was classified into four cover categories: forest vegetation (oldgrowth tropical semi-deciduous forest and secondary forest of different ages), agricultural areas (including active pastures and crop-fields), terrain devoid of vegetation (uncovered soil), and water-filled sinkholes (locally known as cenotes). Classification errors due to bands in the SPOT images were corrected using ArcView 3.2 (ESRI, 1996). For each site, a circle with a $2.5 \mathrm{~km}$ radius (centered at the sampling location) was used to estimate the area cover and distribution of the four land-cover types. The $5 \mathrm{~km}$ separation of sampling sites and the $2.5 \mathrm{~km}$ size of the circle used to characterize the landscape structure were selected by considering the distance that $D$. rotundus usually moves each night from its roosting site to its feeding areas, which is approximately between 2 and $5 \mathrm{~km}$ (Trajano 1996).

The variables selected to characterize the landscape structure around each sampling site included forest cover, agricultural land cover, number of agricultural patches, aggregation index of agricultural patches and landscape heterogeneity. These variables were estimated using the software FRAGSTATS version 3.3 (McGarigal et al. 2002) on the classified SPOT images. Eight pixel rule was set as size of the neighborhood to patch analysis, this considers all eight adjacent pixels, including the 


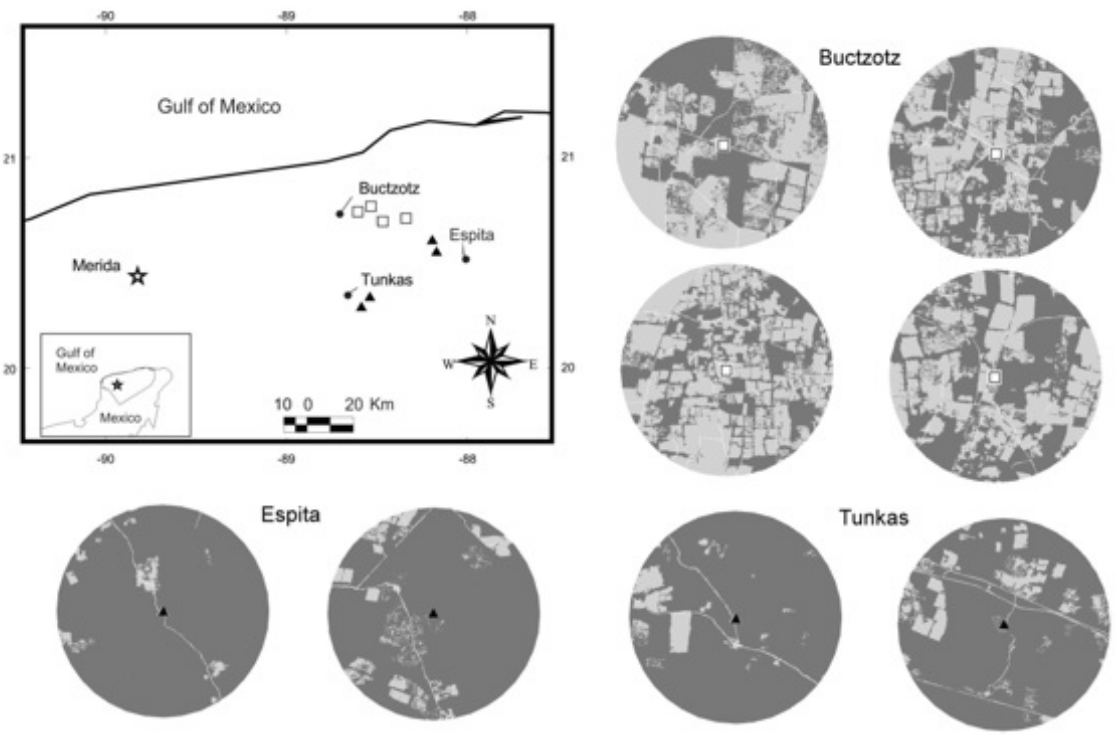

Figure 1. Location of bat sampling sites in Yucatan, Mexico, for two landscape matrices: forest patches within pasture matrix (squares) and within continuous forest matrix (triangles). Forest cover in the circle of $2.5 \mathrm{~km}$ radius around each sampling site is in dark gray.

four orthogonal and four diagonal neighbors to the focal pixel. Neighborhood size was used to calculate the number of agricultural patches and aggregation index of agricultural patches. The areas of forest and agricultural cover were expressed as percentage and were defined as the sum of the area $\left(\mathrm{m}^{2}\right)$ of all patches of each cover type (forest or agricultural) divided by the total area of the circle $(2.5 \mathrm{~km}$ radius) and multiplied by 100 . The number of agricultural areas could be zero or it was an integer value that represented the number of discrete production units within each circle of $2.5 \mathrm{~km}$ radius. The agricultural aggregation index indicated the number of adjacencies between the pixels of this cover type (edges shared between pixels of the same type) divided by the maximum number of possible adjacencies for that cover type and multiplied by 100 ; thus, the result was expressed as a percentage. For example, the maximum aggregation value (100\%) is achieved when the cover type consists of a single and compact patch. The landscape heterogeneity index was equivalent to the Shannon diversity index, where the relative abundances of species were replaced by the proportion of patches that belonged to a given cover type ( $\mathrm{Pi})$. The formula for calculating landscape heterogeneity in FRAGSTATS is: $\sum_{i=1}^{m}(P i * \ln P i)$

\section{Bat capture}

We captured $D$. rotundus during four sampling seasons at each site. Five $12 \times 2.6 \mathrm{~m}$ understory mist nets with a mesh size of $36 \mathrm{~mm}$ (AFO Mist Nest, Manomet, Inc.) were placed at each site for three nonconsecutive nights in each season. In the four sites dominated by pastures, the nets were placed within a small forest fragment surrounded by pasture, and the nets were not far from the forest-pasture edge. The nets were opened 15 min before sunset and remained open for five consecutive hours. Sampling was conducted between the last and the first quarter based on the lunar calendar; this scheme was selected because vampire bats generally reduce their activity during full-moon nights (Morrison 1978).

Captured bats were identified using the field guides of Medellín et al. (2008) and Reid (2009). After being removed from the net, each captured bat was temporarily placed in a cloth bag for conventional morphometric measurement, tagged with a plastic collar to identify possible recaptures, and finally released at the capture site. We also determined the sex and reproductive condition of each captured bat. 


\section{Statistical analysis}

To evaluate the effects of landscape structural variables on the abundance of $D$. rotundus, a generalized linear model (GLM) with a quasiPoisson distribution was used due to overdispersion of data (Quinn and Keough 2002). In this case, the model included the abundance (cumulative number of individuals) of the vampire bat as the response variable, and the amount of forest cover (\%), amount of agricultural land cover (\%), number of agricultural areas, aggregation index of agricultural areas and landscape heterogeneity as explanatory variables. The global model (including all explanatory variables) was generated using the glm function; then it was simplified to avoid overfitting using the anova function in the statistical package $R$ version 3.2.3. (Crawley 2012).

\section{RESULTS}

With a sampling effort of 96 nights and a total of 2400 net-hours, a total of 193 individuals were captured. The abundance of $D$. rotundus was greater at sites dominated by a pasture matrix (163 individuals) than at sites dominated by a continuous forest matrix (30 individuals).

Sampling sites located within a pasture matrix were characterized by forest cover less than $60 \%$, a large number of agricultural areas, and high heterogeneity within a $2.5 \mathrm{~km}$ radius. In contrast, the landscape buffers around sites within continuous forest matrix had more than $90 \%$ forest cover, fewer agricultural areas and low heterogeneity values (Table 1). Among the five variables of landscape structure within the $2.5 \mathrm{~km}$ radius around the sampling sites, the GLM with a quasi-Poisson distribution indicated that the landscape heterogeneity $(t=5.36, d f=13, P<$ $0.0001)$ and agricultural aggregation index $(\mathrm{t}=-2.28$, $\mathrm{df}=13, \mathrm{P}<0.039$ ) were significantly and positively related with the abundance of $D$. rotundus. In other words, sites dominated by man-made pastures for cattle rising with some relicts of forest as patches and corridors, support higher abundances of the vampire bat.
Table 1. Landscape variables used to characterize fragmentation of sampling sites within $2.5 \mathrm{~km}$ radius.

\begin{tabular}{lccccc}
\hline Sites & CVF (\%) & CAA (\%) & NAA & AIA (\%) & LH \\
\hline Pasture matrix & & & & & \\
Site 1 & 56.859 & 40.670 & 730 & 95.938 & 0.793 \\
Site 2 & 44.475 & 54.176 & 682 & 96.775 & 0.759 \\
Site 3 & 53.074 & 45.129 & 411 & 97.187 & 0.779 \\
Site 4 & 39.956 & 58.614 & 399 & 97.356 & 0.753 \\
Forest matrix & & & & & \\
Site 1 & 93.881 & 5.685 & 79 & 97.570 & 0.248 \\
Site 2 & 94.701 & 4.954 & 59 & 97.307 & 0.221 \\
Site 3 & 98.775 & 1.066 & 71 & 94.399 & 0.071 \\
Site 4 & 94.720 & 3.200 & 124 & 94.403 & 0.256 \\
\hline $\begin{array}{l}\text { FC: Forest cover, AC: Agricultural cover, NAA: Number of agricul- } \\
\text { tural areas, AlA: Agricultural }\end{array}$ & Aggregation Index y LH: Landscape \\
heterogeneity. & & &
\end{tabular}

\section{DISCUSSION}

The abundance of $D$. rotundus was higher in sites that were immersed within pasture matrices with high levels of forest fragmentation. This pattern was characterized by a large number of agricultural areas and a high landscape heterogeneity within $2.5-\mathrm{km}$ of the sampling site. In contrast, sites that were embedded within large fragments of continuous forest had a much lower abundance of this vampire bat species. In other regions of the state of Yucatan, MacSwiney et al. (2007) captured 51 individuals of $D$. rotundus in sites surrounded by pasturelands with extensive cattle ranching, where this bat species represented the second most abundant species. Currently, the highest levels of forest loss and fragmentation in the state are associated with forest conversion into extensive pastures used for cattle raising, which seems to be the most important factor explaining the higher abundance of $D$. rotundus in sites dominated by a pasture matrix. A similar pattern was reported in the Biosfere Reserve of Los Tuxtlas, where the tropical rainforest has been reduced and heavily fragmented due to land conversion for agricultural activities, i.e., mainly cattle ranching; as a result, the authors found a high capture rate for this bat species (Estrada and CoatesEstrada 2001). The abundance of the vampire bat is expected to be much lower within large tracts of native forest than in areas dominated by pasture; specifically, there are no easily accessible food sources for this hematophagous bats, such as cattle 
and other types of domestic livestock, within nonfragmented forest or in areas with very low levels of fragmentation (Medellín et al. 2000).

Although $D$. rotundus feeds on various species of wild mammals (deer, peccary, and lowland paca), it prefers domestic animals since they are kept at high densities (usually one adult cow per ha of open pasture in the case of cattle) and are frequently confined to small areas at night; moreover, cattle are often kept within enclosures and corrals that are easier to detect at night, unlike the wild vertebrate species that are constantly moving and are found at much lower densities (Voigt and Kelm 2006, Bobrowiec et al. 2015). This fact suggests that $D$. rotundus is highly opportunistic when searching for food, as it commonly approaches rural areas with human settlements, where corrals, chicken coops and pig farms, which typically have confined animals, represent food resources that are valuable and easy to obtain (Bobrowiec 2012). Thus, vampire bat populations are favored by their adaptability to anthropized environments, and they do especially well in landscapes where cattle and other types of domestic livestock are present at high densities for human consumption (Bobrowiec et al. 2015). As a result, we can regard the vampire bat as a good indicator species of human habitat disturbance or of land-use change due to cattle ranching activities in the Neotropics (Medellín 1993).

The aggregation of agricultural areas and the combination of different types of land cover in the surrounding areas of a given site also had a significant effect on the abundance of $D$. rotundus. In the northeastern portion of the state of Yucatan, the proximity of large units dedicated to cattle ranching to areas devoted to other agricultural activities can be considered as a factor that favors the presence of the vampire bat. However, it is important to note that our sampling sites that were located within a highly fragmented landscape still retained some forest cover within the 2.5 $\mathrm{km}$ radius around the sampling site. Thus, in our study, these sites still had at least $40 \%$ forest cover. This result indicates that the presence of some forest, even if it is confined at small forest fragments (mean area: $1.4 \mathrm{ha}$ ), seems to be important for the move- ments of vampire bats through the fragmented landscape. This was also reported by Avila-Cabadilla et al. (2012) for tropical deciduous forest in Chamela, Mexico, where $D$. rotundus used riparian forest belts that crossed agricultural areas as movement corridors to reach livestock. Similarly, Medina et al. (2007) studied a landscape of dry forest fragmented by cattle ranching activities in Nicaragua and reported that the largest number of $D$. rotundus captures occurred in riparian forest fragments, live fences and pastures with high forest cover. These results suggest that, in addition to the presence and aggregation of man-made pastures, the presence of woody vegetation remnants, such as forest patches and tree corridors that protect rivers, are fundamental landscape elements used by the vampire bats to reach food sources. In fact, according to reports of SAGARPA-SENASICA (2016), ranches with highest vampire attacks were surrounded by secondary vegetation, pastures and agricultural areas. Similarly, roosting sites of vampire bats were located in areas with secondary vegetation, tropical dry forest, pastures and agricultural areas. This information highlights the importance of tree cover for the presence of $D$. rotundus.

The association of different vegetation and land-cover types favors the heterogeneity of the landscape (Fischer and Lindenmayer 2007) and plays an important role in the movement and maintenance of $D$. rotundus populations. Furthermore, this heterogeneity not only facilitates their movement through anthropized landscapes but also increases the variety of sites that can be used as roosting sites in their foraging areas. The presence of different types of vegetation and land uses that form a heterogeneous mosaic may translate into the presence of different resources that promote landscape complementarity (Dunning et al. 1992). Several studies have documented that $D$. rotundus can use different vegetation types, such as agroforestry systems, silvopastoral systems, man-made pastures, live fences, riparian forests, secondary vegetation and old-growth preserved forests (Estrada and Coates-Estrada 2001, García-Morales et al. 2013). The presence of trees or arboreal elements of different compositions and origins can be used by this vampire bat as night roosts 
during their search for food in landscapes dominated by pastures (Estrada and Coates-Estrada 2001).

We recorded a relatively high abundance of $D$. rotundus within pasture-dominated landscapes, similar to previous reports in Yucatan (MacSwiney et al. 2007). Although this study did not evaluate the effect of cattle density on the abundance of vampire bats in these contrasting landscape matrices, previous works have found higher abundances of this bat species in cattle raising areas than in natural ones (Delpietro et al. 1992). Recently, it has been reported that vampire bat demography shows a strong positive correlation with livestock biomass, with higher proportion of reproductive individuals in sites with high livestock density (Becker et al. 2018).

\section{CONCLUSIONS}

It is crucial to note that the intense deforestation in Yucatan due to forest conversion into pas- tures or slash-and-burn crop fields could increase the presence and negative effects on cattle productivity of the vampire bat over the short-to-medium term. Therefore, it is important to continue developing prevention measures, such as the timely vaccination of cattle and other domestic animals, which is more profitable and effective than attempting to control the vampire bat population.

\section{ACKNOWLEDGEMENTS}

We thank Alan Cuxim, Marisol Meza, Richard Chi, Juan Manuel Pech, Cristina MacSwiney and José Guemez for helping with fieldwork. Bat sampling was carried out under permit number 04316 (SEMARNAT). This work was supported by funding assigned to Javier Laborde (INECOL/200030-10281), with which fieldwork of this project was carried out. CONACyT Mexico provided a Retention scholarship to Beatriz Bolívar (No. 2014 PCl-1054-11-14).

\section{LITERATURE CITED}

Anderson A, Shwiff S, Gebhardt K, Ramírez AJ, Kohler D, Lecuona L (2012) Economic evaluation of vampire bat (Desmodus rotundus) rabies prevention in Mexico. Transboundary and Emerging Diseases 61: 140-146.

Andrade HM (2010) Transformación de los sistemas naturales por actividades antropogénicas. In: DuránGarcía R, Méndez-González ME (eds) Biodiversidad y desarrollo humano en Yucatán. CICY, PPD-FMAM, CONABIO, SEDUMA. Mérida, Yucatán, México. pp: 316-319.

Avila-Cabadilla LD, Sanchez-Azofeifa GA, Stoner KE, Alvarez-Añorve MY, Quesada M, Portillo-Quintero CA (2012) Local and landscape factors determining occurrence of phyllostomid bats in tropical secondary forests. Plos One 7: e35228. Doi: 10.1371/journal.pone.0035228

Barber A, Tun J, Crespo MB (2001) A new approach on the bioclimatology and potential vegetation of the Yucatan Peninsula (Mexico). Phytocoenologia 31: 1-32.

Bárcenas-Reyes I, Loza-Rubio E, Zendejas-Martínez H, Luna-Soria H, Cantó-Alarcón GJ, Milión-Suazo F (2015) Epidemiological trends in bovine paralytic rabies in central Mexico, 2001-2013. Revista Panamericana de Salud Pública/Pan American Journal of Public Health 38: 396-402.

Becker DJ, Czirják GÁ, Volokhov DV, Bentz AB, Carrera JE, Camus MS, et al. (2018) Livestock abundance predicts vampire bat demography, immune profiles and bacterial infection risk. Philosophical Transactions of the Royal Society B 373: 20170089. Doi: 10.1098/rstb.2017.0089

Bennett AF, Saunder DA (2010) Habitat fragmentation and landscape change. In: Sodhi NS, Ehrlich PR (eds) Conservation biology for all. Oxford University Press. UK. pp: 88-106.

Bobrowiec PED (2012) A chiroptera preliminary survey in the middle Madeira River region of Central Amazonia, Brazil. Mammalia 76: 277-283. 
Bobrowiec PED, Lemes MR, Gribel R (2015) Prey preference of the common vampire bat (Desmodus rotundus, Chiroptera) using molecular analysis. Journal of Mammalogy 96: 54-63.

Crawley MJ (2012) Generalized Linear Model. In: Crawley MJ (ed) The R book. Second edition. Ed. Chichester, John Wiley and Sons, Ltd. UK. pp: 511-526.

Delpietro HA, Marchevsky N, Simonetti E (1992) Relative population densities and predation of the common vampire bat (Desmodus rotundus) in natural and cattle-raising areas in north-east Argentina. Preventive Veterinary Medicine 14: 13-20.

Duch GJ (1988) La conformación territorial del estado de Yucatán-los componentes del medio físico-Centro Regional de la Península de Yucatán (CRUPY), México. Universidad Autónoma de Chapingo. México. 472p.

Dunning JB, Danielson B, Pulliam HR (1992) Ecological processes that affect populations in complex landscapes. Oikos 65: 169-175.

Durán-García R, García-Contreras G (2010) Distribución espacial de la vegetación. In: Durán-García R, MéndezGonzález ME (eds) Biodiversidad y desarrollo humano en Yucatán. CICY, PPD-FMAM, CONABIO, SEDUMA. Mérida, Yucatán, México. pp: 131-135.

ESRI (1996) Environmental Systems Research Institute, Inc. ArcView GIS v. 3.2. Software. USA.

Estrada A, Coates-Estrada R (2001) Bat species richness in live fences and in corridors of residual rain forest vegetation at Los Tuxtlas, Mexico. Ecography 24: 94-102.

Fenton MB, Acharya L, Audet D, Hickey MBC, Merriman C, Obrist MK, et al. (1992) Phyllostomid bats (Chiroptera: Phyllostomidae) as indicators of habitat disruption in the Neotropics. Biotropica 24: 440-446.

Fischer J, Lindenmayer DB (2007) Landscape modification and habitat fragmentation: a synthesis. Global Ecology and Biogeography 16:265-280.

Flores JS, Espejel-Carvajal I (1994) Etnoflora Yucatanense: Tipos de vegetación de la Península de Yucatán, Mérida. Universidad Autónoma de Yucatán. 35p.

García D (2011) Efectos biológicos de la fragmentación de hábitats: nuevas aproximaciones para resolver un viejo problema. Ecosistemas 20: 1-10.

García E (2004) Modificaciones al sistema de clasificación climática de Köppen. Instituto de Geografía, Universidad Nacional Autónoma de México. México. 98p.

García-Morales R, Badano El, Moreno CE (2013) Response of Neotropical bat assemblages to human land use. Conservation Biology 27: 1096-1106.

INEGI (2007) Anuario estadístico del estado de Yucatán. Instituto Nacional de Estadística, Geografía e Informática. Tomos I. México. 37p.

INEGI (2011) Serie V. Uso de suelo y Vegetación: escala 1:250, 000. México.

Kalko EKV, Handley CO (2001) Neotropical bats in the canopy: diversity, community structure, and implications for conservation. Plant Ecology 153: 319-333.

MacSwiney MC, Vilchis P, Clarke FM, Racey PA (2007) The importance of cenotes in conserving bat assemblages in the Yucatan, Mexico. Biological conservation 136: 499-509.

Martinuzzi SN, Withey JC, Pidgeon AM, Plantinga AJ, McKerrow AJ, Williams SG, et al. (2015) Future land-use scenarios and the loss of wildlife habitats in the southeastern United States. Ecological Applications 25: 160-171. 
Mayen F (2003) Haematophagous bats in Brazil, their role in rabies transmission, impact on public health, livestock industry and alternatives to an indiscriminate reduction of bat population. Journal of Veterinary Medicine 50: 469-472.

McGarigal K, Cushman SA, Neel MC, Ene E (2002) FRAGSTATS: spatial pattern analysis program for categorical maps. Produced by the authors at the University of Massachusetts, Amherst. USA. http://www.umass.edu/ landeco/research/fragstats/fragstats.html. Data consulted: October 8, 2013

Medellín RA (1993) Estructura y diversidad de una comunidad de murciélagos en el trópico húmedo mexicano. In: Medellín RAC, Medellín GRA, Ceballos G (eds). Avances en el estudio de los mamíferos de México. Asociación Mexicana de Mastozoología. Publicaciones especiales. México. pp: 333-354.

Medellín RA, Equihua M, Amin MA (2000) Bat diversity and abundance as indicators of disturbance in Neotropical rainforests. Conservation Biology 14: 1666-1675.

Medellín RA, Arita HT, Sánchez-Herrera O (2008) Identificación de los murciélagos de México: clave de campo. Segunda Edición. Instituto de Ecología, UNAM-CONABIO. México. 83p.

Medina A, Harvey CA, Merlo DS, Vílchez S, Hernández B (2007) Bat diversity and movement in an agricultural landscape in Matiguás, Nicaragua. Biotropica 39: 120-128.

Mialhe PJ (2014) Preferential prey selection by Desmodus rotundus (E. Geoffroy, 1810, Chiroptera, Phyllostomidae) feeding on domestic herbivores in the municipality of São Pedro - SP. Brazilian Journal of Biology 74: 579-584.

Morrison DW (1978) Lunar phobia in a neotropical fruit bat, Artibeus jamaicensis (Chiroptera: Phyllostomidae). Animal Behaviour 26: 852-855.

Quinn GP, Keough MJ (2002) Experimental design and data analysis for biologists. Cambridge University Press. UK. 527p.

Ramírez-Delgado J, Christman Z, Schmook B (2014) Deforestation and fragmentation of seasonal tropical forests in the southern Yucatán, Mexico (1990-2006). Geocarto International 29: 822-841.

Reid F (2009) A field guide to the mammals of Central America and Southeast Mexico. Second edition. Oxford University Press. New York. USA. 346p.

Robinson TP, Wint GRW, Conchedda G, Van Boeckel TP, Ercoli V, Palamara E, et al.(2014) Mapping the global distribution of livestock. Plos One 9: e96084. Doi: 10.1371/journal.pone.0096084

SAGARPA-SENASICA (2016) Vigilancia de las zoonosis y control de murciélago hematófago. http://www.cenaprece.salud.gob.mx/programas/interior/zoonosis. Date consulted: November 16, 2018.

Trajano E (1996) Movements of cave bats in southeastern Brazil, with emphasis on the population ecology of the common vampire bat, Desmodus rotundus (Chiroptera). Biotropica 28: 121-129.

Voigt CC, Kelm DH (2006) Host preference of the common vampire bat (Desmodus rotundus; Chiroptera) assessed by stable isotopes. Journal of Mammalogy 87: 1-6.

Wilson MC, Chen X-Y, Corlett RT, Didham RK, Ding P, Holt RD, et al. (2016) Habitat fragmentation and biodiversity conservation: key findings and future challenges. Landscape Ecology 31: 219-227. 
